\title{
Potassium requirements of pasture on pumice soils
}

\author{
J. MORTON ${ }^{1}$, A. STAFFORD ${ }^{2}$ and M. HAWKE ${ }^{3}$ \\ ${ }^{1}$ Ballance Agri-Nutrients, PB 2290, Hastings \\ ${ }^{2}$ Ballance Agri-Nutrients, PB 12503, Tauranga \\ ${ }^{3} \mathrm{MFH}$ Consultancy, $R D$ 4, Rotorua \\ jmorton@ballance.co.nz
}

\section{Abstract}

On pumice soils at Mamaku near Rotorua (initial quick test (QT) K 4) and Pouakani near Whakamaru (initial QT K 2), pasture yield responses to applications of $0,75,150,300$ and $600 \mathrm{~kg} \mathrm{~K} / \mathrm{ha} / \mathrm{yr}$ (all as three equal split applications) plus $300 \mathrm{~kg} \mathrm{~K} / \mathrm{ha} / \mathrm{yr}$ applied once in the spring were measured for 3 years. There was a significant total pasture dry matter (DM) response to up to $150 \mathrm{~kg} \mathrm{~K} / \mathrm{ha} / \mathrm{yr}$ at Mamaku in two and to $75 \mathrm{~kg} \mathrm{~K} /$ $\mathrm{ha} / \mathrm{yr}$ in one of the first three years, but no significant difference $(\mathrm{P}<0.05)$ between $300 \mathrm{~kg} \mathrm{~K} / \mathrm{ha} / \mathrm{yr}$ applied once or as split applications. The contribution of clover to DM yield was increased significantly by up to $75 \mathrm{~kg}$ $\mathrm{K} / \mathrm{ha} / \mathrm{yr}$ in the second year and $150 \mathrm{~kg} \mathrm{~K} / \mathrm{ha} / \mathrm{yr}$ in the third year. In the fourth year when a common rate of $130 \mathrm{~kg} \mathrm{~K} / \mathrm{ha}$ was applied to all of the $\mathrm{K}$ plots, there was a significant pasture and clover DM contribution response up to the previous $300 \mathrm{~kg} \mathrm{~K} / \mathrm{ha} / \mathrm{yr}$ at Mamaku. At Pouakani there was a significant pasture yield response to up to $300 \mathrm{~kg} \mathrm{~K} / \mathrm{ha} / \mathrm{yr}$ in the second and up to $75 \mathrm{~kg} \mathrm{~K} / \mathrm{ha} / \mathrm{yr}$ in the third year. There was no significant difference in pasture yield between a single spring application and three split applications of $300 \mathrm{~kg}$ $\mathrm{K} / \mathrm{ha} / \mathrm{yr}$. Clover contribution to DM yield was increased significantly by up to $300 \mathrm{~kg} \mathrm{~K} / \mathrm{ha} / \mathrm{yr}$ in all of the first three years. In the fourth year, there was no significant difference in pasture DM yield between previous $\mathrm{K}$ treatments, but a carryover effect on clover contribution to pasture DM yield. Pasture relative yield (RY) was lower than the average derived from other trials on pumice soils at the same soil QT K levels and nearmaximum pasture yield $(97 \% \mathrm{RY})$ was achieved at a lower soil QT K level (3-4) for these sites than for the overall average (5). It was concluded that at these low QT K levels, high rates of $\mathrm{K}$ are required for maximum pasture production on pumice soils but these may not be economic. These higher rates of K increased soil QT K levels above the target range for near-maximum pasture production (7-10) at the end of the growth season, only for it to drop to below this range by the next spring because of high winter leaching rates. Therefore on those pumice soils where it is difficult to achieve the target range for soil QT K, it is recommended that $\mathrm{K}$ be applied at least three times in a growth season to ensure an adequate supply from fertiliser.
Keywords: pasture yield response, potassium, soil quick test potassium, pumice soils

\section{Introduction}

The acidic glasses and feldspars in pumice soils have a large particle size and are slow to weather, consequently providing little potassium $(\mathrm{K})$ for plant needs (Metson $\&$ Gibson 1974). In a series of nine trials on pumice soils, Toxopeus \& Gordon (1971) reported a response to $63 \mathrm{~kg} \mathrm{~K} / \mathrm{ha} / \mathrm{yr}$ on seven sites with a quick test (QT) K of 5 or less. Two further trials carried out for four years measured maximum pasture production at $63 \mathrm{~kg} \mathrm{~K} / \mathrm{ha} /$ $\mathrm{yr}$ with the main period of response between October and March. Edmeades et al. (2010) reported on a large database of $\mathrm{K}$ response trials on pumice soils which showed that, on average, $95 \%$ relative yield (RY) was achieved at a soil QT K level of 5. Earlier, a similar database established a target range of soil QT K 7-10 for near-maximum pasture production $(97 \% \mathrm{RY})$ on pumice soils (Roberts \& Morton 2009).

This series of two trials over 4 years was carried out to repeat some of this work and determine whether soil $\mathrm{K}$ levels could be increased to high levels and maintained there with economic rates of $\mathrm{K}$ fertiliser on pumice soils.

\section{Materials and methods \\ Sites}

The trials were carried out on flat paddocks on dairy farms on a Mamaku loamy sand soil at Mamaku near Rotorua and an Oruanui sandy loam at Pouakani near Whakamaru. The pastures were predominantly ryegrass and browntop with little clover present initially. Annual rainfall at Mamaku over the duration of the trial was $2078 \mathrm{~mm}$ and at Pouakani was $1350 \mathrm{~mm}$. Initial soil QT $\mathrm{K}$ levels were 4 at Mamaku and 2 at Pouakani.

\section{Treatments}

The trials were laid down in a randomised block design with six replicates of each treatment. In September of each year from 2009 to 2011 at both sites, potassium chloride was applied to each $4 \times 1.5 \mathrm{~m}$ plot to give rates of $0,75,150,300$ and $600 \mathrm{~kg} \mathrm{~K} / \mathrm{ha} / \mathrm{yr}$ split evenly between September, November, and February. The 300 $\mathrm{kg} \mathrm{K} / \mathrm{ha}$ treatment was also applied once in September. 
In the fourth year at both sites (2012/13), a uniform rate of $130 \mathrm{~kg} \mathrm{~K} / \mathrm{ha}$ split as in the previous years or in one application was applied to all of the plots that had previously received $\mathrm{K}$. Basal applications of $\mathrm{P}, \mathrm{S}, \mathrm{Mg}$ and Mo were applied annually.

\section{Measurements}

Soil samples were taken from each plot before $\mathrm{K}$ application in each spring to $75 \mathrm{~mm}$ depth. In autumn from the second year $(2010 / 11)$ plot samples were also taken at 75-150 and 150-300 mm depth and bulked for each treatment. Mowing cuts were taken every 4-6 weeks from October to May to measure pasture dry matter (DM) yield. About $50-60 \%$ of the clippings were returned to the plots after each cut to simulate return of excreta from dairy cows. Before cutting, a visual assessment of clover cover in each plot was carried out. At each cut, a clover dissection was carried out in each treatment and the clover analysed for $\mathrm{K}$ content.

\section{Statistical analysis}

Analysis of variance (SAS) was carried out on the pasture DM yield, contribution of clover to pasture DM yield and spring soil QT K results. The same statistical package was used to derive a best fit relationship between soil QT K and relative pasture DM yield.

\section{Results}

\section{Soil QT K}

In Years 2 and 3, soil QT K levels were significantly higher than the control $(\mathrm{P}<0.05)$ at rates of $300 \mathrm{~kg} \mathrm{~K} /$ $\mathrm{ha} / \mathrm{yr}$ and above at Mamaku in 2 out of 3 years (Figure 1). At Pouakani, soil QT K levels were significantly higher than the control at rates of $150 \mathrm{~kg} \mathrm{~K} / \mathrm{ha} / \mathrm{yr}$ and greater in Years 2 and 3 (Figure 1). In the fourth year when there was a common rate of $130 \mathrm{~kg} \mathrm{~K} / \mathrm{ha} / \mathrm{yr}$, only the previous rates of 300 and $600 \mathrm{~kg} \mathrm{~K} / \mathrm{ha} / \mathrm{yr}$ applied in the first three years achieved a significant increase over control. Autumn soil QT K levels were always higher than spring levels at both sites, increasing to $12-14$ at $600 \mathrm{~kg} \mathrm{~K} / \mathrm{ha}$ in Year 2 (data not presented). Soil sampling at a depth of $75-150 \mathrm{~mm}$ showed that $600 \mathrm{~kg} \mathrm{~K} / \mathrm{ha} / \mathrm{yr}$ was required to increase QT K levels above 4 which indicated that $\mathrm{K}$ at depth had little effect on pasture growth at most rates (results not shown).

\section{Pasture DM yield}

In 2 of the first 3 years, there was a significant response in pasture DM yield up to $150 \mathrm{~kg} \mathrm{~K} / \mathrm{ha} / \mathrm{yr}$ at Mamaku and to $75 \mathrm{~kg} \mathrm{~K} / \mathrm{ha} / \mathrm{yr}$ in the other year. A significant response was measured up to $300 \mathrm{~kg} \mathrm{~K} / \mathrm{ha} / \mathrm{yr}$ at Pouakani in the second year and up to $75 \mathrm{~kg} \mathrm{~K} / \mathrm{ha} / \mathrm{yr}$ in the third year (Table 1). In all years, there was no significant difference in pasture DM yield between $300 \mathrm{~kg} \mathrm{~K} / \mathrm{ha} / \mathrm{yr}$ split or single spring application. At

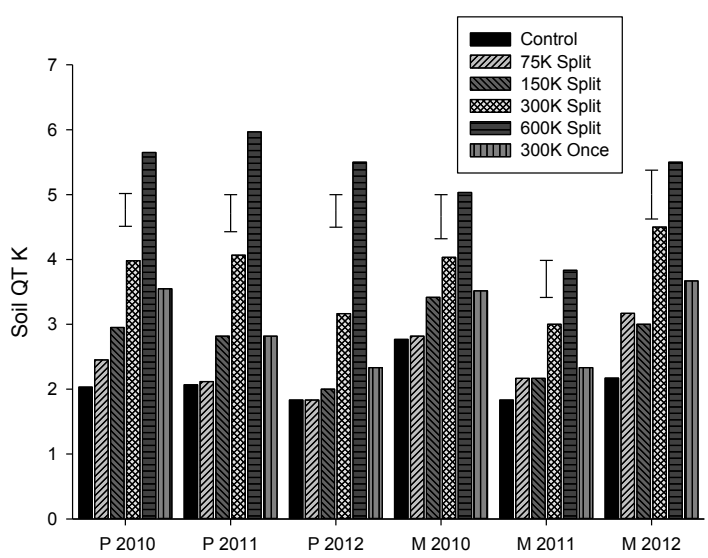

Figure 1 Soil QT K levels measured before first $\mathrm{K}$ application in Years 2, 3 and 4 at Pouakani (P) and Mamaku (M)

Mamaku, there was a significant response in DM yield in the fourth year up to the previously applied 300 $\mathrm{kg} \mathrm{K} / \mathrm{ha} / \mathrm{yr}$. In the fourth year at Pouakani, there was a significant response in pasture $\mathrm{DM}$ yield to $\mathrm{K}$ over control $(\mathrm{P}<0.05)$, but no significant difference between previous $\mathrm{K}$ treatments.

Relationship between soil QT K and pasture DM yield The relationship for each treatment $\times$ year combined over both sites is shown in Figure 2 with pasture DM

Table 1 Annual pasture DM yield results for the two sites ( $\mathrm{kg} \mathrm{DM} / \mathrm{ha}$ ). The least significant difference at the $\mathrm{P}<0.05$ level is given

\begin{tabular}{|c|c|c|c|c|}
\hline Treatment & $2009 / 2010$ & $2010 / 2011$ & $2011 / 2012$ & $2012 / 2013$ \\
\hline \multicolumn{5}{|l|}{ Mamaku } \\
\hline Control & 9324 & 9965 & 6822 & 5313 \\
\hline 75 K Split & 9299 & 10969 & 7949 & 8369 \\
\hline 150K Split & 10304 & 11511 & 9392 & 8672 \\
\hline 300K Split & 9937 & 11828 & 9451 & 9758 \\
\hline 600K Split & 9365 & 11155 & 9191 & 9519 \\
\hline 300K Once & 9161 & 11579 & 9234 & 9796 \\
\hline $\operatorname{LSD}_{(\mathrm{P}<0.05)}$ & 813 & 906 & 765 & 1034 \\
\hline \multicolumn{5}{|l|}{ Pouakani } \\
\hline Control & 4479 & 7179 & 6307 & 8032 \\
\hline 75 K Split & 5026 & 9634 & 9297 & 11623 \\
\hline 150K Split & 4947 & 9895 & 10653 & 11385 \\
\hline 300K Split & 5733 & 11755 & 11782 & 12882 \\
\hline 600K Split & 5652 & 11035 & 10799 & 13527 \\
\hline 300K Once & 5435 & 12716 & 11695 & 12295 \\
\hline $\operatorname{LSD}_{(\mathrm{P}<0.05)}$ & 803 & 1300 & 1463 & 2033 \\
\hline
\end{tabular}




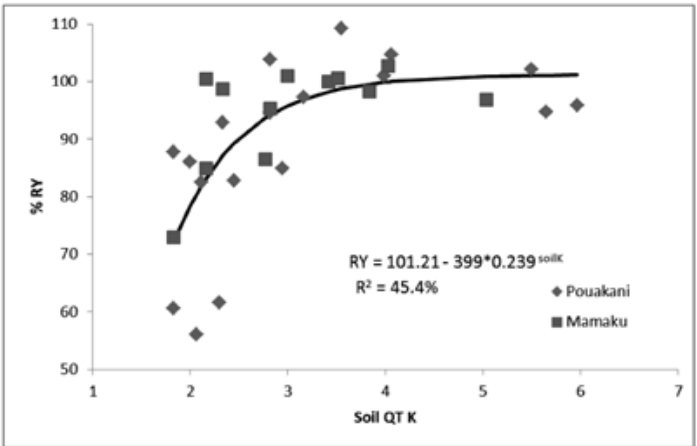

Figure 2 Relationship between soil QT K and relative yield from combined data at Mamaku and Pouakani

yield expressed as a percentage of maximum yield (RY). There was a moderately strong significant curvilinear relationship with $97 \%$ RY being achieved at a soil QT K level of 3-4.

\section{Clover DM contribution}

At Mamaku, when pasture DM yield was multiplied by clover cover, there was no significant difference in clover DM contribution between treatments in the first year, but a significant response up to $75 \mathrm{~kg} \mathrm{~K} / \mathrm{ha} / \mathrm{yr}$ in the second and $150 \mathrm{~kg} \mathrm{~K} / \mathrm{ha} / \mathrm{yr}$ in the third year (Table 2). At Pouakani, there was a significant response in clover DM contribution up to $300 \mathrm{~kg} \mathrm{~K} / \mathrm{ha} / \mathrm{yr}$ in all three years. In the fourth year at both sites, where the lower rate of

Table 2 Annual clover contribution to total DM yield (kg/ha) at the two sites

\begin{tabular}{|c|c|c|c|c|}
\hline Treatment & 2009/2010 & 2010/2011 & 2011/2012 & $2012 / 2013$ \\
\hline \multicolumn{5}{|l|}{ Mamaku } \\
\hline Control & 3779 & 3026 & 1441 & 1145 \\
\hline 75 K Split & 3890 & 4369 & 2610 & 4094 \\
\hline 150K Split & 4520 & 4953 & 4497 & 4165 \\
\hline 300K Split & 4149 & 5169 & 4320 & 5233 \\
\hline 600K Split & 4088 & 5960 & 5164 & 5858 \\
\hline 300K Once & 3873 & 5791 & 4060 & 4635 \\
\hline LSD $(P<0.05)$ & 890 & 1185 & 1096 & 953 \\
\hline \multicolumn{5}{|l|}{ Pouakani } \\
\hline Control & 452 & 1347 & 1373 & 2352 \\
\hline 75 K Split & 720 & 4562 & 4649 & 6322 \\
\hline 150K Split & 877 & 5719 & 6404 & 6505 \\
\hline 300K Split & 1283 & 8060 & 8553 & 8908 \\
\hline 600K Split & 1233 & 7114 & 7415 & 9615 \\
\hline 300K Once & 1033 & 9170 & 8600 & 7896 \\
\hline LSD $(P<0.05)$ & 393 & 2446 & 1492 & 1902 \\
\hline
\end{tabular}

$130 \mathrm{~kg} \mathrm{~K} / \mathrm{ha}$ was applied to all previous $\mathrm{K}$ plots, there was a significant response in clover contribution in treatments that had previously received $300 \mathrm{~kg} \mathrm{~K} / \mathrm{ha} / \mathrm{yr}$.

\section{Clover K content}

These results bulked for every cut on a treatment basis could not be analysed but clover $\mathrm{K}$ content was in the adequate range of 2.0-2.5\% (Roberts \& Morton 2009) at rates of $75 \mathrm{~kg} \mathrm{~K} / \mathrm{ha} / \mathrm{yr}$ and above at both sites in Year $1,150 \mathrm{~kg} \mathrm{~K} / \mathrm{ha} / \mathrm{yr}$ and above at Mamaku in Years 2 and 3 and $300 \mathrm{~kg} \mathrm{~K} / \mathrm{ha} / \mathrm{yr}$ and above at Pouakani in Years 2-4 (results not shown).

\section{Discussion}

All of the previous $\mathrm{K}$ research data that contributes to the relationship between soil QT K and relative yield (RY), as summarised by Roberts \& Morton (2009), indicates that on average, for pumice soils, $80 \%$ and $91 \%$ respectively of maximum pasture yield was achieved at the initial soil QT K of 2 at Pouakani and 4 at Mamaku. The corresponding relative yields of $61 \%$ and $85 \%$ at the initial soil QT K levels of 2 and 4 at the reported trial sites were much lower than for the average of all the sites. Therefore relatively high rates of $\mathrm{K}$ were required to achieve near-maximum pasture yield, especially at Pouakani. In addition, 95\% RY was achieved at a soil QT K level of 3 from these sites compared with 5 from the overall database for published soils (Edmeades et al. 2010), which indicates that these pumice soils do not require such a high soil QT K for near-maximum pasture production compared with the average pumice soil.

It has been contended that on coarser pumice soils and under higher rainfall (eg. Mamaku site), it is difficult to increase soil QT K levels above 4 unless very high rates of $\mathrm{K}$ are applied (M. O'Connor pers. comm.). This is attributed to excessive $\mathrm{K}$ leaching during drainage, especially over winter. This contention is supported by the reported elevation of soil QT K levels from spring to autumn measurements at rates of $\mathrm{K}$ of $300 \mathrm{~kg} / \mathrm{ha} / \mathrm{yr}$ and above only for them to drop back at the next spring sampling to their previous spring levels. When the 300 $\mathrm{kg} \mathrm{K} / \mathrm{ha} / \mathrm{yr}$ treatment was only applied once compared to three applications per year, autumn soil QT K levels were much lower which suggests that a significant proportion of the high rate was leached in drainage during the growth season which would be expected at these high annual rainfalls, especially at Mamaku. Once the high annual rates of $\mathrm{K}$ were reduced in the fourth year, it was difficult to maintain the high soil QT K levels achieved at the previously applied high $\mathrm{K}$ rates. However, despite this, there was a generally a residual effect in total and clover DM yield from the previously applied $\mathrm{K}$ rates of up to $300 \mathrm{~kg} \mathrm{~K} / \mathrm{ha} / \mathrm{yr}$, but the trial was not carried on long enough to measure whether the 
residual effect would persist longer than one year.

On most dairy farms in this situation, the $\mathrm{K}$ applications are split 2-4 times in the growth season depending on annual rainfall to maintain soil QTK levels of 3-4 rather than the target range of 7-10 for pumice soils (Roberts \& Morton 2009) so there is a regular K supply from the fertiliser applications. Also, excessive leaching of high rates of $\mathrm{K}$, if soil drainage occurs soon after application, is minimised. Although there was no significant difference in DM yield between $300 \mathrm{~kg} \mathrm{~K} / \mathrm{ha} / \mathrm{yr}$ applied once or three times per year in these trials, possibly at this high rate there was more than enough $\mathrm{K}$ to supply the needs of the pasture for the whole growth season despite the occurrence of leaching. At a lower rate of K, the split applications may have shown an increase in annual pasture DM yield. Nevertheless, the significantly lower soil QT K levels measured from $300 \mathrm{~kg} \mathrm{~K} / \mathrm{ha} / \mathrm{yr}$ applied once compared with split applications, indicated that there was more leaching of $\mathrm{K}$ from the higher single annual application. In addition there could have been luxury uptake of $\mathrm{K}$ from the large single application rate and removal of some of that $\mathrm{K}$ in clippings.

Rational fertiliser application rates are based on economics. The econometric decision support software Overseer 3, whose response function is derived from the database of all appropriate $\mathrm{K}$ trials, has modelled an economically optimal rate of $100-120 \mathrm{~kg} \mathrm{~K} / \mathrm{ha} / \mathrm{yr}$ at both sites to maintain a soil QT K of 5 . These trials have indicated the difficulty of maintaining QT K 5 at these sites at a lower rate of $\mathrm{K}$. A practical option would be to apply $120-150 \mathrm{~kg} \mathrm{~K} / \mathrm{ha} / \mathrm{yr}$ in three applications of $40-50 \mathrm{~kg} \mathrm{~K} / \mathrm{ha}$. This annual rate of $\mathrm{K}$ is similar to the average optimal rate measured in the first 3 years of the trial. Because it is more robust to provide advice from a number of trials rather than one or two, it makes more sense to analyse the results from these sites in the context of results from other $\mathrm{K}$ trials on pumice soils rather than just concentrate on individual trials. The use of Overseer 3 allows this analysis.

Analysis of the $\mathrm{K}$ content of clover in late spring when growth is normally not limited by climatic factors is also an effective way of assessing the adequacy of the fertiliser K programme. In these trials clover K content was consistent with pasture DM yield responses.

\section{Conclusions}

1. At two pumice soil sites with low initial soil QT $\mathrm{K}$ levels (2-4), significant increases in pasture and clover yield were measured at rates of $75-300 \mathrm{~kg} \mathrm{~K} /$ ha/yr over 3years.

2. Even very high rates of $300-600 \mathrm{~kg} \mathrm{~K} / \mathrm{ha} / \mathrm{yr}$ failed to elevate the soil QT K levels into the target range for near-maximum pasture production of 7-10 for pumice soils at the start of each pasture growth season. Therefore for coarse textured pumice soils under high rainfall, the aim should be to meet pasture $\mathrm{K}$ demand rather than a target QT K range.

3. Clover $\mathrm{K}$ content in the adequate range was achieved at annual rates of $150-300 \mathrm{~kg} \mathrm{~K} / \mathrm{ha}$.

4. Taking into account economic returns based on Overseer 3, an appropriate $\mathrm{K}$ fertiliser programme for these pumice soils under moderate to high rainfall, would be three split applications of $40-50 \mathrm{~kg} \mathrm{~K} / \mathrm{ha} /$ yr.

\section{ACKNOWLEDGEMENTS}

We thank Sarah Anderson, BOP Farm and Pastoral Research for the field work and Chris Smith, AgResearch for analysing the data. The project was funded by Ballance Agri-Nutrients.

\section{REFERENCES}

Edmeades, D.C.; Morton, J.D.; Waller, J.E.; Metherell, A.K.; Roberts, A.H.C; Carey, P. 2010. The diagnosis and correction of potassium deficiency in New Zealand pastoral soils, a review. New Zealand Journal of Agricultural Research 53: 151-173.

Metson, A.J.; Gibson, J.E. 1974. Potassium pp. 88-91 In: Soil groups of New Zealand. Part 1 Yellow-brown pumice soils. Government Printer, Wellington.

Roberts, A.H.C.; Morton, J.D. 2009. Fertiliser use on New Zealand dairy farms. New Zealand Fertiliser Association. 48 pp.

Toxopeus, M.R.J.; Gordon, R.B. 1971. Rational fertilizer practice on pumice soils. Proceedings of the New Zealand Grassland Association 33: 35-41. 


\title{
Novel approaches to improving growth of pasture legumes at low phosphorus levels
}

\author{
S.N. NICHOLS and J.R. CRUSH \\ AgResearch, Ruakura Research Centre, Private Bag 3123, Hamilton \\ shirley.nichols@agresearch.co.nz
}

\begin{abstract}
Strategies to reduce the economic and environmental costs of phosphate $(\mathrm{P})$ fertiliser use in mixed pastures through plant breeding are focussed on inefficiencies in the legume component. One approach is breeding within white clover for root systems with improved $\mathrm{P}$ acquisition properties. Selection for root length per unit root weight (specific root length, SRL) showed that higher SRL plants could retain more biomass in the above ground fraction with decreasing soil $\mathrm{P}$, whereas plants with lower SRL diverted more biomass to roots. Back cross $1\left(\mathrm{BC}_{1}\right)$ generation interspecific hybrids between white clover and a wild relative, Trifolium uniflorum L., may possess additional root traits influencing $\mathrm{P}$ acquisition. In glasshouse experiments, some $T$. repens $\times T$. uniflorum hybrids, back-crossed to white clover, also exhibited higher shoot dry weight than their white clover cultivar parents at low nutrient supply levels and low to intermediate soil Olsen P. This, combined with low internal $\mathrm{P}$ concentrations, suggests some $\mathrm{BC}_{1}$ hybrids may be more tolerant of low soil $\mathrm{P}$ than white clover. Differences in both $\mathrm{P}$ acquisition ability and internal $\mathrm{P}$ use efficiency may contribute to the observed yield differences. There are good prospects for delivery of new-generation clover cultivars with improved phosphate use efficiency to New Zealand farmers.
\end{abstract}

Keywords: phosphorus, white clover, Trifolium uniflorum, interspecific hybridisation, root morphology, P-efficiency

\section{Introduction}

Legumes are an important component of temperate grassland systems, through their contribution to feed quality, seasonal growth and nitrogen $(\mathrm{N})$ fixation. Phosphorus (P) is essential for legume production, and phosphate fertiliser is a major cost in most New Zealand farm budgets. The environmental impacts of $\mathrm{P}$ losses on surface water quality (Monaghan et al. 2007), and the footprint costs of transporting phosphate rock to New Zealand (Ledgard et al. 2011) are increasing concerns. In addition, phosphate rock is a finite resource for which there is an increasing demand worldwide (Lott et al. 2011), and security of future supply of high quality rock is likely to become an important issue.

The development of P-efficient forage legumes that allowed reduced $\mathrm{P}$ fertiliser inputs would yield significant economic and environmental benefits. New Zealand's grass/clover pastures have an in-built inefficiency in that grasses compete very strongly with white clover (Trifolium repens L.) for P, and much more superphosphate is needed to grow white clover with grasses than on its own (Mouat \& Walker 1959). Although earlier research suggested it should be possible to breed more P-efficient white clover cultivars, attempts to demonstrate improved P-use efficiency in the field were unsuccessful (Caradus \& Dunn 2000).

This paper describes some of our current work on P-efficiency in white clover, which focusses on two areas - improved P acquisition and improved internal efficiency. Interspecific hybridisation is a new approach, introducing new genes and traits into the white clover gene pool. We are studying hybrids between white clover and a wild relative Trifolium uniflorum L. to determine whether P-efficiency or tolerance of low soil $\mathrm{P}$ can be improved through hybridisation.

\section{Methods}

\section{White clover root selections}

A total of 845 plants from a polycross of MiddleEastern material were grown in hydroponic culture and digital images of the root systems were analysed using WinRhizo ${ }^{\mathrm{TM}}$ software. Stolon tip cuttings were taken from genotypes selected for high or low specific root length (SRL, root length/unit root dry weight) with 10 genotypes in each group, and grown in $15 \mathrm{~cm}$ pots containing $0.9 \mathrm{~kg}$ of dry Horotiu sandy loam subsoil collected from a dairy pasture. $\mathrm{K}_{2} \mathrm{SO}_{4}$ and $\mathrm{MgO}$ were added to bring levels of $\mathrm{K}$ and $\mathrm{Mg}$ up to target values for dairy farming on the soil type. The soil had been premixed with $\mathrm{CaHPO}_{4}$ to give Olsen $\mathrm{P}$ values of 6 , 9, 14 and $20 \mathrm{mg} \mathrm{P} / \mathrm{kg}$ soil. There were three clonal replicates of each plant genotype at every $\mathrm{P}$ level in a row/column design, inoculated with a commercial rhizobium inoculant. Plants were harvested after 13 weeks, and shoots and roots separated, dried at $70^{\circ} \mathrm{C}$ for $>24$ hours, and weighed. 


\section{Interspecific hybrids}

The hybrid clover entries were backcross $1\left(\mathrm{BC}_{1}\right)$ families, created by crossing $\mathrm{F}_{1} T$. repens $\times T$. uniflorum hybrids to one or both of two contrasting white clover parental cultivars ('Grasslands Kopu II' and 'Crusader'), to which they are compared. In some cases, T. uniflorum accessions were also included. There were ten replicates of each clover entry. Experiments were conducted in a glasshouse at AgResearch, Ruakura Research Centre. At harvest, plants were separated into roots and shoots; or roots, stolons and leaves. Total macronutrients, or $\mathrm{P}$ concentrations only, were analysed in shoot or leaf material. Leaf inorganic $\mathrm{P}\left(\mathrm{P}_{\mathrm{i}}\right)$ was also measured in Experiment 2, and calculated as a fraction of total leaf P.

Experiment 1 - Plants were grown in $1 \mathrm{~m}$ deep $\times$ $150 \mathrm{~mm}$ diameter tubes of sand culture. A low ionic strength (LIS) nutrient solution (Blamey et al. 1991) was applied to all tubes five times per week, and plants were harvested after 8 months of growth. Dry weight data were natural $\log$ transformed, and analysed by ANOVA in Minitab. Macronutrient data was analysed by REML in Genstat.

Experiment 2 - This was conducted in 1.24 litre pots of sand culture. Three nutrient treatments were applied three times per week - a highly concentrated Long Ashton solution, LIS, and half-strength LIS. Plants were harvested after 4.5 months of growth. Data were analysed using linear mixed modelling (LMM) with REML in Genstat. Hybrid families are compared with their respective white clover cultivar parent.

Experiment 3 - This pot experiment used the same soil and basal nutrients as the SRL experiment, with $\mathrm{CaHPO}_{4}$ mixed through each pot to provide Olsen $\mathrm{P}$ levels of $6,7,9,14$, and $20 \mathrm{mg} \mathrm{P} / \mathrm{kg}$ soil. Plants were harvested after 13 weeks, and root morphological traits were measured on the first lateral root from each plant, using WinRhizo ${ }^{\mathrm{TM}}$ software. Data were analysed using LMM with REML in Genstat.

\section{Results and Discussion}

\section{White clover root selections}

Root morphology (diameters, lengths) and architecture (branching patterns) can play a significant role in the acquisition of nutrients, as demonstrated by the competition between ryegrass and white clover for soil P (Jackman \& Mouat 1972). Our approach here was to select for SRL in white clover, in order to develop populations which would be more competitive for $\mathrm{P}$ in a mixed sward. Heritability for root traits in white clover is high, and selection has been shown to bring about changes in root morphology (Caradus \& Woodfield 1998).

Root:shoot ratios increased with decreasing soil $\mathrm{P}$, due to reallocation of biomass to roots for acquisition

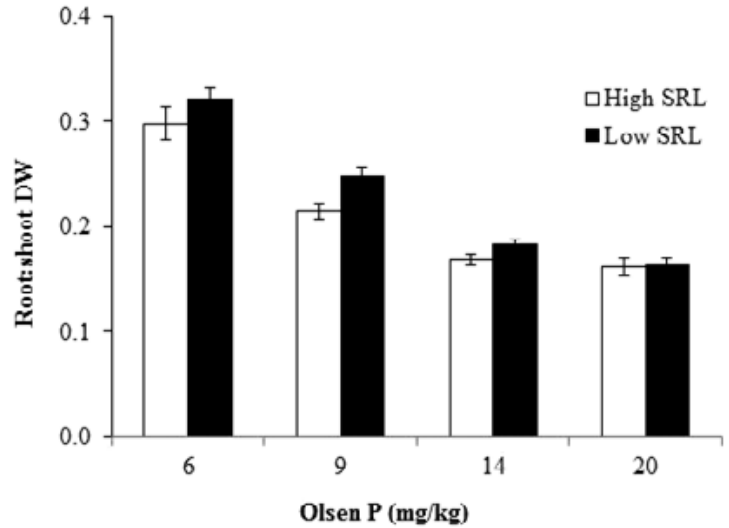

Figure 1 Mean root:shoot dry weight (DW) ratios of high and low specific root length (SRL) white clover selections at four soil Olsen $\mathrm{P}$ levels.

of the limiting resource (Figure 1). However the ratios increased significantly $(\mathrm{P}<0.001)$ less in high SRL selections as their finer roots could acquire more $\mathrm{P}$, limiting the need to reallocate biomass to roots. This enabled plants with fine roots to maintain up to $20 \%$ higher shoot production. There was substantial variation in P response within both SRL groups, and a re-examination of the roots suggested that differences in root hair length and density might explain some of this variation. Root hairs are a relatively effective way for plants to increase root surface area and P uptake. For white clover, selecting for root hair length can increase the volume of the soil explored by roots, $\mathrm{P}$ absorption and growth (Caradus 1979, 1981). The next step is to combine high SRL with long, dense root hairs.

\section{Interspecific hybrids}

In $1 \mathrm{~m}$ deep sand tubes, shoot DW of Kopu II $\mathrm{BC}_{1}$ was 10 times greater than 'Kopu II'; Crusader $\mathrm{BC}_{1}$ was 24 times greater than 'Crusader', and the T. uniflorum accessions were up to 19 times greater than white clover (Figure 2). This contradicted the expected pattern. Under field conditions, Nichols et al. (2014b) observed significantly lower dry matter $(\mathrm{DM})$ production in $T$. repens $\times$ T. uniflorum $\mathrm{BC}_{1}$ and $\mathrm{BC}_{2}$ hybrids compared with white clover, and in T. uniflorum compared with hybrid families as well as white clover. Although the nutrient solution used here has been used successfully in similar experiments with perennial ryegrass, there appear to be species differences in the adequacy of nutrient supply, most likely driven by differences in root traits which affect $\mathrm{P}$ acquisition.

Most shoot mineral concentrations were adequate for white clover growth in the clover entries that were analysed, but P concentrations (Figure 2) were well below the published (McNaught 1970) critical level of $3400 \mathrm{mg} / \mathrm{kg}$. Given the differences in DW production, 


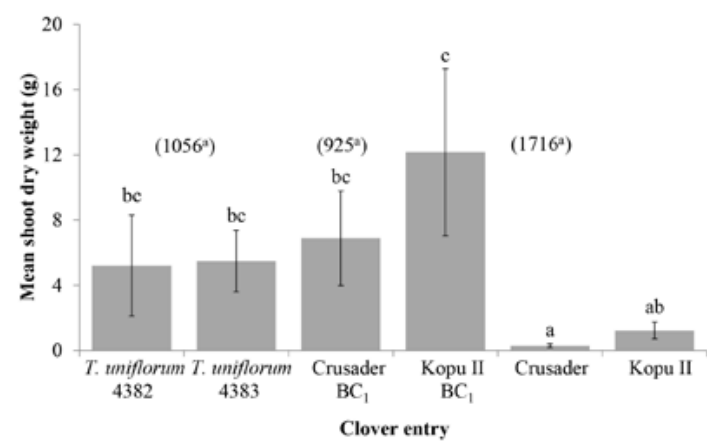

Figure 2 Mean shoot dry weight of 8-month-old plants of T. uniflorum, Crusader $\mathrm{BC}_{1}$, Kopu II $\mathrm{BC}_{1}$, 'Crusader' and 'Kopu II', in sand culture. Values in brackets are back-transformed mean shoot $\mathrm{P}$ concentrations $(\mathrm{mg} / \mathrm{kg})$. Means with the same letter are not significantly different at the $5 \%$ level.

this suggested that $T$. repens $\times$ T. uniflorum hybrids might be more tolerant than white clover of low external $\mathrm{P}$ concentrations. There is little information available on the edaphic adaptations of T. uniflorum.

The sand culture pot experiment confirmed these results, but also showed that not all hybrids are equal. In the LIS solution, three of the four hybrid families were significantly larger than their parental white clover cultivar. This dropped to two out of four in the more dilute $1 / 2$ LIS solution (Table 1 ). Shoot DWs of the hybrids were up to five times larger than their white clover parents. The effect of decreasing nutrient solution strength on shoot DW also varied among hybrid families (Table 2).

The shoot $\mathrm{P}$ concentration of Kopu II $\mathrm{BC}_{1} \mathrm{~B}$ was significantly lower than 'Kopu II' and Kopu II BC A (Table 1), indicating an ability to grow at lower internal P concentrations. This entry was also the least affected by decreasing nutrient solution strength (Table
2), and had the highest shoot DWs in the LIS and $1 / 2$ LIS treatments. Shoot inorganic $\mathrm{P}\left(\mathrm{P}_{\mathrm{i}}\right)$ concentration in Kopu II BC 1 B was also significantly lower than 'Kopu II' and Kopu II $\mathrm{BC}_{1}$ A, as was the fraction of the total $\mathrm{P}$ pool in inorganic form (Table 1). A high proportion of $\mathrm{P}_{i}$ is one explanation for white clover's high P requirement (Hart \& Jessop 1983). The lower $P_{i}$ fraction of one hybrid may, therefore, have contributed to differences in growth at low external P supply.

The results from sand culture were confirmed by the pot experiment using soil. At Olsen P $20 \mathrm{mg} / \mathrm{kg}$, shoot DW of Kopu II $\mathrm{BC}_{1} \mathrm{C}$ was $35 \%$ greater than its white clover parent and a second hybrid family. Shoot $\mathrm{P}$ concentrations did not differ among the clover entries, so internal P use efficiency did not differ. Meaningful comparisons of SRL between entries are difficult because of the complication of possible differences in root tissue density (Nichols 2012). However, there were differences in other root traits which may have influenced growth through increased $\mathrm{P}$ acquisition. In Kopu II $\mathrm{BC}_{1} \mathrm{C}$, the root:shoot ratio was considerably higher in the lowest $\mathrm{P}$ treatment than in the other entries, and decreased sharply with increasing P supply (Figure 3). Scavenging for $P$ in low $P$ soils, and rapid shoot growth when $\mathrm{P}$ deficiency is alleviated, are valuable

Table 2 Effect of decreasing nutrient solution strength from Long Ashton to LIS, and Long Ashton to $1 / 2$ LIS, on mean shoot and root dry weight (DW) in 'Kopu II' compared with Kopu II BC 1 hybrids. LIS, low ionic strength.

\begin{tabular}{lcccc}
\hline & \multicolumn{2}{c}{ Long Ashton to LIS } & \multicolumn{2}{c}{ Long Ashton to $1 / 2$ LIS } \\
\hline & Shoot DW & Root DW & Shoot DW & Root DW \\
\hline 'Kopu II' & $-87 \%$ & $-84 \%$ & $-80 \%$ & $-77 \%$ \\
Kopu II BC 1 A & $-66 \%$ & $-66 \%$ & $-83 \%$ & $-82 \%$ \\
Kopu II BC B $_{1}$ & $-53 \%$ & $-52 \%$ & $-61 \%$ & $-62 \%$ \\
\hline
\end{tabular}

Table 1 Shoot dry weight (DW), overall shoot $P$ concentration, and the overall fraction of total shoot $P$ as inorganic $P\left(P_{i}\right)$, with three nutrient treatments, for 'Kopu II' compared with Kopu II BC hybrids, and 'Crusader' compared with Crusader $\mathrm{BC}_{1}$ hybrids. LIS, low ionic strength; LA, Long Ashton. Means within columns with the same letter are not significantly different at the $5 \%$ level. Upper case letters indicate comparisons between Kopu II BC Bnd $_{1}$ rusader $\mathrm{BC}_{1}$ hybrids with the same F1 parent.

\begin{tabular}{lccccc}
\hline & & Shoot DW & & Shoot P (mg/kg) & Fraction $\mathbf{P}_{\mathrm{i}}(\%)$ \\
\hline & $1 / 2$ LIS & LIS & LA & & \\
\hline 'Kopu II' & $0.39^{\mathrm{a}}$ & $0.25^{\mathrm{a}}$ & $1.98^{\mathrm{a}}$ & $934^{\mathrm{a}}$ & $60.5^{\mathrm{a}}$ \\
Kopu II BC, A & $0.40^{\mathrm{a}}$ & $0.77^{\mathrm{b}}$ & $2.30^{\mathrm{a}}$ & $1091^{\mathrm{b}}$ & $56.9^{\mathrm{a}}$ \\
Kopu II BC, B & $1.14^{\mathrm{b}}$ & $1.36^{\mathrm{b}}$ & $2.91^{\mathrm{a}}$ & $803^{\mathrm{cA}}$ & $48.5^{\mathrm{bA}}$ \\
'Crusader' & $0.21^{\mathrm{a}}$ & $0.17^{\mathrm{a}}$ & $1.64^{\mathrm{a}}$ & & \\
Crusader BC, A & $0.46^{\mathrm{b}}$ & $0.34^{\mathrm{ab}}$ & $1.35^{\mathrm{a}}$ & & \\
Crusader BC, B & $0.22^{\mathrm{a}}$ & $0.36^{\mathrm{b}}$ & $1.96^{\mathrm{a}}$ & $931^{\mathrm{B}}$ & $58.8^{\mathrm{B}}$ \\
\hline
\end{tabular}




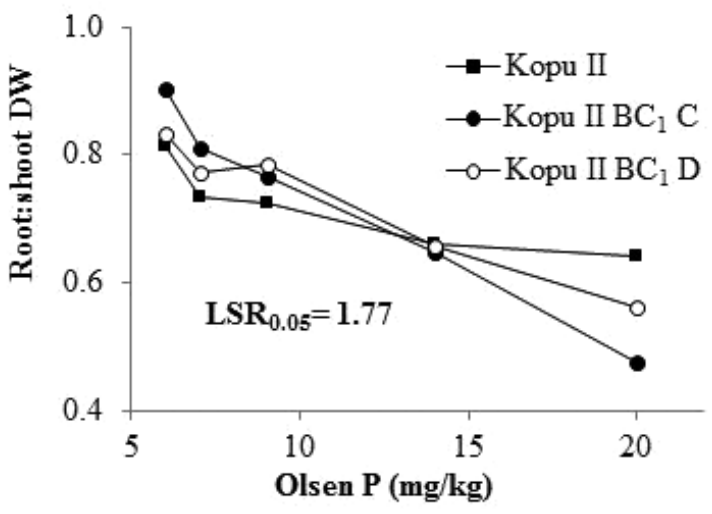

Figure 3 Mean root:shoot dry weight ratios of 'Kopu II', Kopu II BC $C_{1}$, and Kopu II BC D in soil at five Olsen P levels.

traits. This hybrid family also had significantly longer roots $(\mathrm{P}<0.001)$ with more branching (more root tips/ unit root length, $\mathrm{P}=0.015$ ) than 'Kopu II'. Differences in root traits in this hybrid have also been observed in hydroponic culture, and appear to have been inherited from the T. uniflorum parent. T. uniflorum and Kopu II $\mathrm{BC}_{1} \mathrm{~A}$ have a simpler branching pattern than white clover and Kopu II BC B, being closer to a herringbone arrangement (Nichols 2012). This architecture may be more efficient at nutrient acquisition, and indicative of adaptation to low soil fertility (Fitter 1987; Fitter \& Stickland 1991).

History shows that selection for increased internal $\mathrm{P}$ efficiency in white clover is not straightforward, because the interaction between genotype and environment clearly has a considerable impact on the expression of this trait (Caradus \& Dunn 2000). Testing "P-efficient" $T$. repens $\times T$. uniflorum hybrids in the field will, therefore, be vital. The competitiveness of ryegrass roots, which drives the high $\mathrm{P}$ fertilisation requirement of mixed pasture, suggests that $\mathrm{P}$ acquisition may be more important than internal efficiency. However, gains in utilisation may still be made by incorporating new clover genetic material through hybridisation. It is possible that both improved acquisition and internal efficiency may be operating in this material, either in combination or potentially in segregating populations. Even if only modest improvements in P efficiency are gained, the combination of this with other traits inherited from T. uniflorum, such as improved drought resistance (Nichols et al. 2014a), could provide significant benefits. Apart from the additive effect of these two traits on growth, their interaction may also be important, as soil $\mathrm{P}$ is known to influence the effects of low soil moisture on white clover growth (Singh et al. 1997). Nutrient mobility can also be affected at soil moisture levels which have no effect in themselves on plant water relations (Nye \& Tinker 1977).
The results show there are good prospects for delivery of clover cultivars with enhanced phosphate use efficiency to New Zealand farmers. This will allow a reduction in phosphate fertiliser input per unit farm production, that will improve farm profitability while reducing $\mathrm{P}$ losses to waterways.

\section{ACKNOWLEDGEMENTS}

Lily Ouyang, Kati Ruppert and Bridget Wise for technical support; Vanessa Cave and Chikako van Koten for statistical assistance. This work was funded by MBIE (contract C02X0810), DairyNZ (contract FD617), and the Pastoral 21 Research Programme (a collaborative venture between DairyNZ, Fonterra, Dairy Companies Association of New Zealand, Beef + Lamb NZ and MBIE).

\section{REFERENCES}

Blamey, F.P.C.; Edmeades, D.C.; Asher, C.J.; Edwards, D.G.; Wheeler, D.M. 1991. Evaluation of solution culture techniques for studying aluminium toxicity in plants. pp. 905-912. In: Plant-soil interactions at low pH. Eds. Wright, R. J.; Baligar, V. C.; Murrmann, R. P. Kluwer Academic Press, Dordrecht.

Caradus, J.R. 1979. Selection for root hair length in white clover (Trifolium repens L.). Euphytica 28: 489-494.

Caradus, J.R. 1981. Effect of root hair length on white clover growth over a range of soil phosphorus levels. New Zealand Journal of Agricultural Research 24: 353-358.

Caradus, J.R.; Dunn, A. 2000. Adaptation to low fertility hill country of white clover lines selected for differences in response to phosphorus. New Zealand Journal of Agricultural Research 43: 63-69.

Caradus, J.R.; Woodfield, D.R. 1998. Genetic control of adaptive root characteristics in white clover. Plant and Soil 200: 63-69.

Fitter, A.H. 1987. An architectural approach to the comparative ecology of plant root systems. New Phytologist 106 (Suppl.): 61-77.

Fitter, A.H.; Stickland, T.R. 1991. Architectural analysis of plant root systems 2 . Influence of nutrient supply on architecture in contrasting plant species. New Phytologist 118: 383-389.

Hart, A.L.; Jessop, D. 1983. Phosphorus fractions in trifoliate leaves of white clover and lotus at various levels of phosphorus supply. New Zealand Journal of Agricultural Research 26: 357-361.

Jackman, R.H.; Mouat, M.C.H. 1972. Competition between grass and clover for phosphate. II. Effect of root activity, efficiency of response to phosphate, and soil moisture. New Zealand Journal of Agricultural Research 15: 667-675. 
Ledgard, S.F.; Boyes, M.; Brentrup, F. 2011. Life cycle assessment of local and imported fertilisers used on New Zealand farms. pp. 1-11. In: Occasional Report 24. Eds. Currie, L.D.; Christensen, C.L. Fertilizer and Lime Research Centre, Massey University, Palmerston North.

Lott, J.N.A.; Kolasa, J.; Batten, G.D.; Campbell, L.C. 2011. The critical role of phosphorus in world production of cereal grains and legume seeds. Food Security 3: 451-462.

McNaught, K.J. 1970. Diagnosis of mineral deficiencies in grass-legume pastures by plant analysis. pp. 334-338. In: Proceedings of the XIth International Grassland Congress.

Monaghan, R.M.; Hedley, M.J.; Di, H.J.; McDowell, R.W.; Cameron, K.C.; Ledgard, S.F. 2007. Nutrient management in New Zealand pastures - recent developments and future issues. New Zealand Journal of Agricultural Research 50: 181-201.

Mouat, M.C.H.; Walker, T.W. 1959. Competition for nutrients between grasses and white clover. I. Effect of grass species and nitrogen supply. Plant and Soil 11: $30-40$.
Nichols, S.N. 2012. Introgression of root and shoot characteristics in Trifolium repens $\times$ Trifolium uniflorum interspecific hybrids. $\mathrm{PhD}$. thesis. Lincoln University, New Zealand. http://hdl.handle. net/10182/5091

Nichols, S.N.; Hofmann, R.W.; Williams, W.M. 2014a. Drought resistance of Trifolium repens $\times$ Trifolium uniflorum interspecific hybrids. Crop and Pasture Science: http://dx.doi.org/10.1071/CP14067

Nichols, S.N.; Hofmann, R.W.; Williams, W.M. 2014 b. The effect of interspecific hybridisation with Trifolium uniflorum on key white clover characteristics. Field Crops Research 161: 107-117.

Nye, P.H.; Tinker, P.B. 1977. Solute movement in the soil-root system. University of California Press, Berkeley. 342 pp.

Singh, D.K.; Sale, P.W.G.; McKenzie, B.M. 1997. Water relations of white clover (Trifolium repens L.) in a drying soil, as a function of phosphorus supply and defoliation frequency. Australian Journal of Agricultural Research 48: 675-682. 